\title{
Fatty polypoid tumour of the bronchus
}

\author{
D. M. D. EVANS ANDE.H. HORTON \\ From the Group Pathology Laboratory, St. David's Hospital, and Glan Ely Hospital, Cardiff
}

The importance of early diagnosis of benign bronchial tumours is widely recognized. Their removal is a fruitful application of lung surgery, provided they are treated before secondary changes in residual lung tissue become irreversible.

Fatty tumour of the bronchus is not usually considered in the differential diagnosis of a bronchial tumour. However, its bronchoscopic presentation is sufficiently characteristic for the diagnosis to be suspected once the features are known. It is to assist in the recognition of these features that the following case is thought worthy of record.

\section{CASE HISTORY}

L. K., a man of 53, was admitted to hospital on 19 January 1962. He was a steel worker and had never worked in a dusty occupation. He complained of cough with mucoid expectoration for the past 10 years. Five months before admission he had had an attack of 'pneumonia' from which he recovered, except for a persistent expiratory wheeze heard loudest over the right hemithorax. The chest was rigid with generalized hyper-resonance. Chest radiography revealed a partial collapse of the right upper lobe. A diagnosis of chronic bronchitis and emphysema was made, and it was considered necessary to exclude an intrabronchial obstructive lesion on the right side. Bronchoscopy on 26 January 1962 revealed a sessile, mobile, red, fleshy tumour protruding from the right upper lobe orifice into the lumen of the main bronchus, partly obstructing it and preventing the further passage of the bronchoscope. The tumour moved freely up and down the main bronchus with respiration.

Biopsy of the lesion demonstrated slight chronic, non-specific, inflammatory change but no recognizable tumour. Bronchography (Fig. 1) revealed that only a small amount of contrast medium entered the contracted upper lobe. A repeat bronchoscopy was therefore performed on 9 February 1962, and a further biopsy was taken. After this the tumour appeared to have been removed in toto. The biopsy was reported as a submucous lipoma of the bronchus (Fig. 2). It was composed of fat interspersed with loose fibromuscular connective tissue. The surface was covered by partially desquamated bronchial mucosa, with slight submucosal infiltration by lymphocytes and plasma cells. Similar infiltrate surrounded a group of bronchial mucous glands (Fig. 3).

As the patient was well and free from wheeze, he was discharged on 9 March 1962. He was re-admitted on 3 April 1962 for re-assessment. The clinical signs were the same as on discharge, and the radiograph was also unchanged. Bronchoscopy on 9 April 1962 again revealed a tumour projecting into the lumen of the right main bronchus from the upper lobe orifice, but it was no longer mobile. It was considered that thoracotomy was imperative, and this was performed by Mr. T. H. L. Rosser on 11 May 1962.

OPERATION The lower and middle lobes were fully expanded and appeared to be healthy. The upper lobe was contracted, fibrosed, and firmly adherent to the surrounding structures. The lung was mobilized, and a sleeve resection of the right upper lobe was performed.

PROGRESS Convalescence was uneventful. The patient was discharged on 2 June 1962 with a satisfactory chest radiograph, and he returned to work free from symptoms.

PATHOLOGY OF OPERATION SPECIMEN The right upper lobe was contracted and showed scarring of the pleura. The orifice of the main bronchus to this lobe was occluded by a rather soft, rounded tumour, reddish in colour, with a smooth surface, measuring approximately $1 \mathrm{~cm}$. in diameter (Fig. 4). Slicing the lobe revealed collapse and fibrosis of the lung distal to the tumour and also showed several large subpleural emphysematous bullae. The tumour was seen to be arising like a tongue from the carinal bronchial wall between the primary divisions of the upper lobe bronchus. Histologically, the tumour was composed mainly of fat, fibrous tissue, and cartilage, together with a number of bronchial glands (Fig. 5). Slight non-specific chronic inflammatory change was also present. No evidence of invasion was demonstrated.

\section{DISCUSSION}

The tumour contained a number of tissues which are normal components of a bronchus. Adipose tissue predominated, with a moderate amount of fibrous tissue and cartilage and a relatively small contribution from the bronchial 

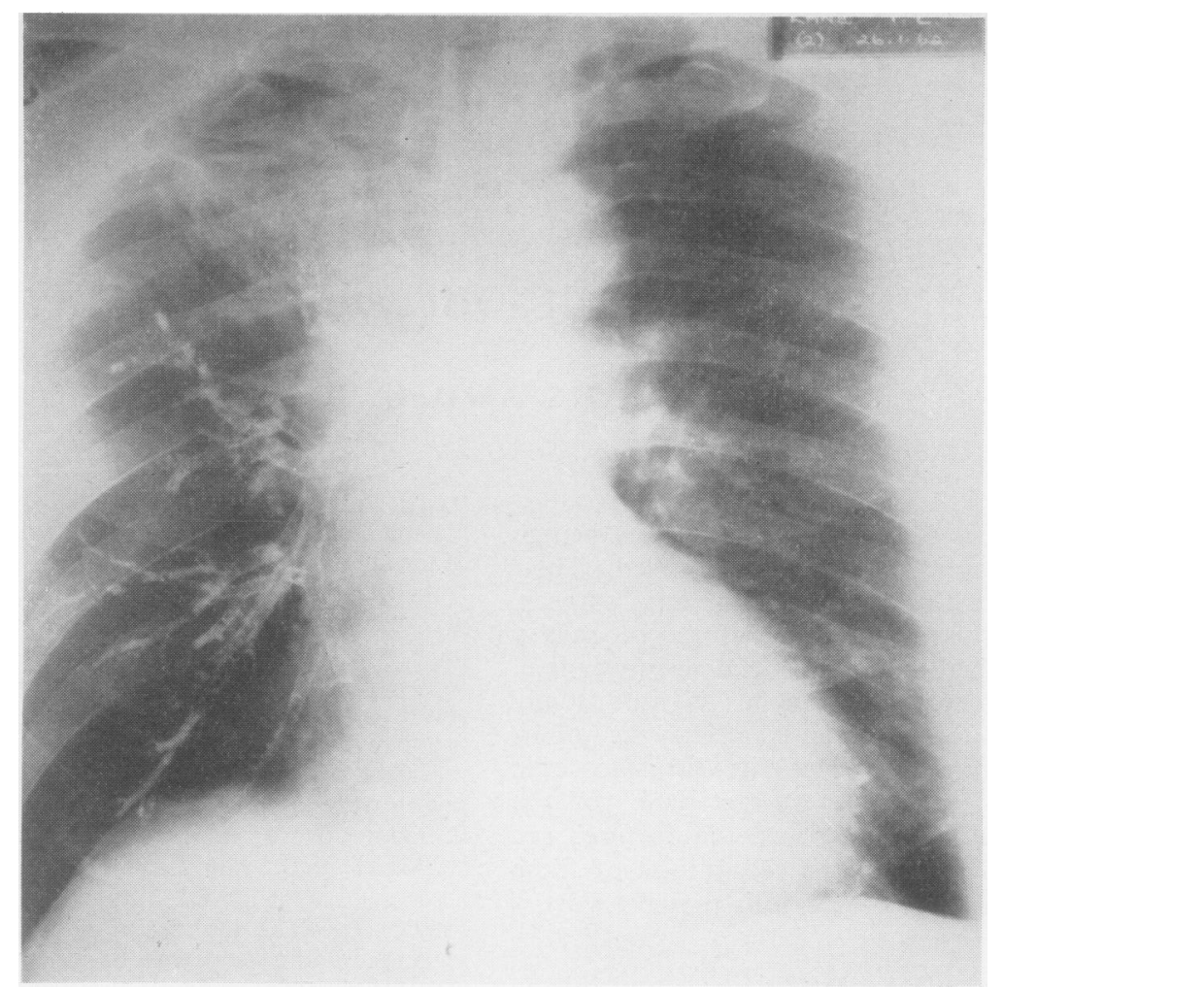

FIG. 1. Bronchogram showing poor entry of radio-opaque medium into the partially collapsed right upper lobe.

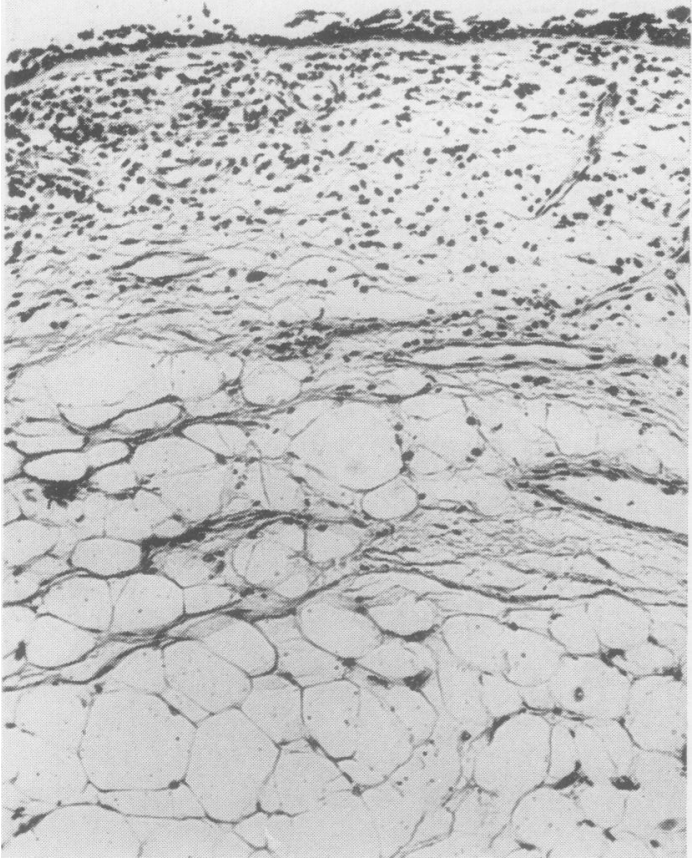

FIG. 2

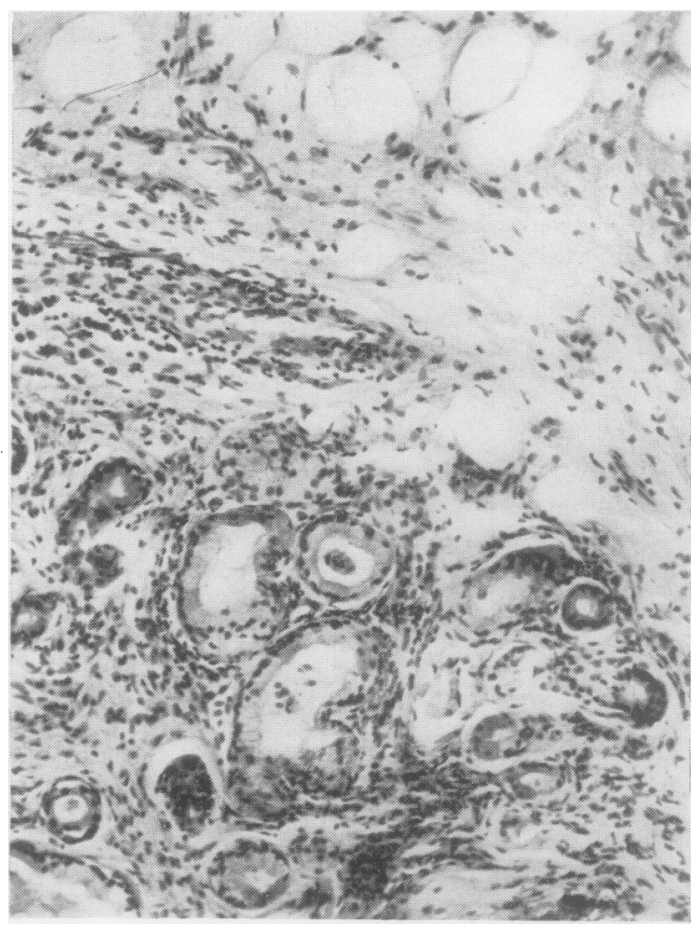

FIG. 3

FIG. 2. Bronchial biopsy. The tumour is composed mainly of adipose tissue traversed by occasional strands of fibrous tissue with superficial non-specific inflammation. $H$. and $E ., \times 120$.

FIG. 3. Mucous glands present in a bronchial biopsy with slight surrounding inflammatory exudate. $H$. and E., $\times 120$. 


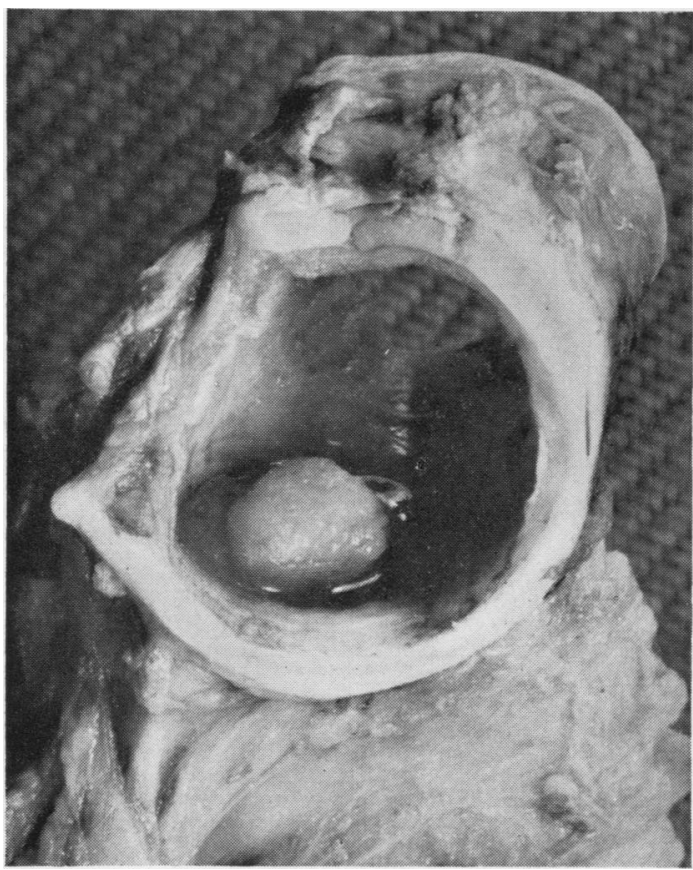

FIG. 4

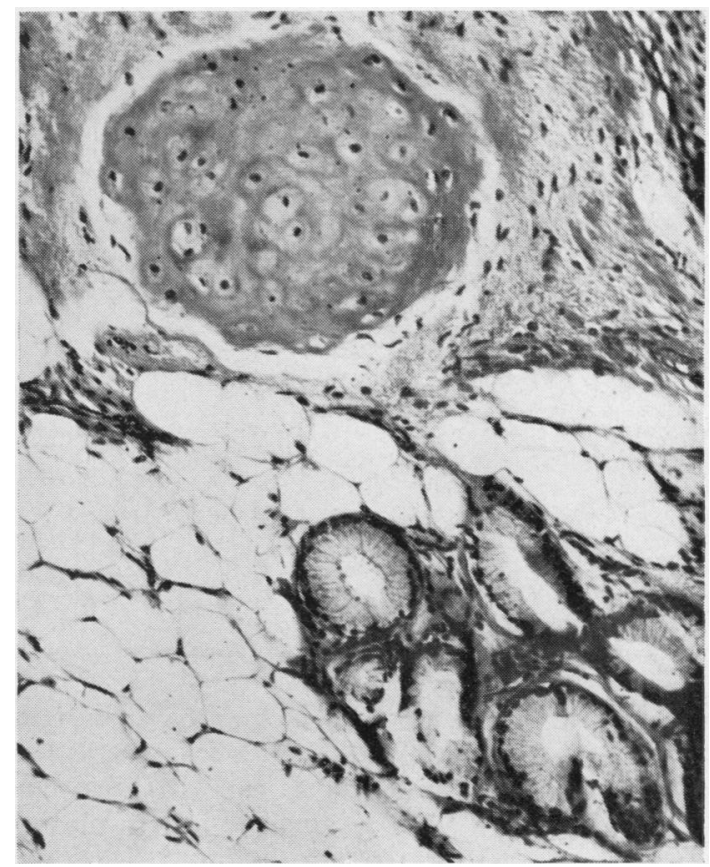

FIG. 5

FIG. 4. Fatty tumour occluding right upper lobe bronchus.

FIG. 5. Section of tumour showing cartilage and mucous glands in addition to adipose and conneciive tissue. $H$. and E., $\times 120$.

glands. It was a variant of the "circumscribed hamartoma' of adults, usually composed mainly of cartilage. The use of the term 'hamartoma' for such tumours is deprecated by Willis (1960), since he does not consider that a developmental anomaly is implicated. It therefore seems preferable to use Möller's term 'mixed tumour'. The present example was a mixed tumour composed mainly of fat.

To determine the characteristics of a fatty tumour of the bronchus a search of the literature was made. Only 12 cases were discovered (see Table). From these and the present case the following conclusions were reached.

SEX The majority of patients were men. Only two out of the 12 patients of known sex were women. Mixed tumours composed mainly of cartilage also show a male predominance, of approximately four to one. The contrast to the predominantly female incidence of adenoma of the bronchus is noteworthy.

AGE Characteristically, the disease presented in middle age. All except one of the 12 patients presented between the ages of 47 and 68 years. The exception, a woman with an apparently simple lipoma of the bronchus, was 29 years of age (Vinson and Pembleton, 1942).

OCCUPATION Insufficient evidence concerning occupation was provided for any conclusion to be reached. In the three cases in which the occupation was known there was no recognized dust hazard.

SITE A main or lobar bronchus was involved in 12 out of 13 cases. The one exception was in the 'upper division of the left upper lobe bronchus' (Carlisle, Leary, and McDonald, 1951).

PRESENTATION The tumour caused irritation of the bronchial mucosa. Cough was thus a constant presenting symptom, often productive and diagnosed as chronic bronchitis (Alstead, 1932). When associated with expiratory wheeze due to partial bronchial obstruction, this was occasionally diagnosed as asthma and was partially relieved by adrenalin (Myerson, 1928). Repeated attacks of pneumonia or pleurisy, sometimes associated with atelectasis or bronchiectasis, were further complications of bronchial obstruction. 
T A B LE

\begin{tabular}{|c|c|c|c|c|c|c|}
\hline & & Age & Sex & Site & Presentation & Histology \\
\hline Feller & (1922) & 68 & $\mathbf{F}$ & Middle lobe bronchus & Not given & $\begin{array}{l}\text { Fat, cartilage, and fibrous } \\
\text { tissue }\end{array}$ \\
\hline Kernan & (1927) & 50 & $\mathbf{M}$ & Middle lobe bronchus & Cough, bronchitis & $\begin{array}{l}\text { Mature fat cells with } \\
\text { fibrous stroma }\end{array}$ \\
\hline Myerson & (1928) & 47 & $\mathbf{M}$ & Main left bronchus & 'Asthma' & $\begin{array}{l}\text { Fibrous tissue and some } \\
\text { fat }\end{array}$ \\
\hline Alstead & $(1932)$ & 68 & $\mathbf{M}$ & Right main bronchus & 'Bronchitis' & $\begin{array}{l}\text { Fibro-aerolar tissue with } \\
\text { a considerable amount } \\
\text { of fat ; also smooth } \\
\text { muscle }\end{array}$ \\
\hline $\begin{array}{l}\text { Jackson and Jackson } \\
\text { Wessler and Rabin } \\
\text { McGlade }\end{array}$ & $\begin{array}{l}(1932) \\
(1932) \\
(1939)\end{array}$ & $\begin{array}{l}64 \\
48 \\
48\end{array}$ & $\begin{array}{l}\mathrm{F} \\
\mathbf{M}\end{array}$ & $\begin{array}{l}\text { Left main bronchus } \\
\text { Left lower lobe bronchus } \\
\text { Left main bronchus }\end{array}$ & $\begin{array}{l}\text { Pneumonia, 'asthma' } \\
\text { Cough and wheeze }\end{array}$ & $\begin{array}{l}\text { Fibrous tissue and fat } \\
\text { Fibro-lipoma } \\
\text { Fibrous tissue and fat }\end{array}$ \\
\hline Vinson and Pembleton & $(1942)$ & 29 & $\mathrm{~F}$ & Left main bronchus & $\begin{array}{l}\text { Fever and productive } \\
\text { cough }\end{array}$ & $\begin{array}{l}\text { Fatty tumour covered } \\
\text { with normal mucosa }\end{array}$ \\
\hline Watts et al. & (1946) & 57 & $\mathbf{M}$ & Left main bronchus & $\begin{array}{l}\text { Cough, weight loss, and } \\
\text { malaise }\end{array}$ & $\begin{array}{l}\text { Mature fat cells with } \\
\text { fibrous stroma }\end{array}$ \\
\hline Carlisle et al. & (1951) & 52 & $\mathbf{M}$ & $\begin{array}{l}\text { Upper division of left upper } \\
\text { lobe bronchus }\end{array}$ & $\begin{array}{l}\text { Fever and productive } \\
\text { cough }\end{array}$ & $\begin{array}{l}\text { Mature fat cells with } \\
\text { scattered mucous bron- } \\
\text { chial glands }\end{array}$ \\
\hline $\begin{array}{l}\text { Liebow } \\
\text { Brewin }\end{array}$ & $\begin{array}{l}(1952) \\
(1952)\end{array}$ & $\overline{63}$ & $\overline{\mathbf{M}}$ & $\begin{array}{l}\text { Upper left stem bronchus } \\
\text { Left main bronchus }\end{array}$ & $\begin{array}{l}\text { Cough, wheeze, and } \\
\text { dyspnoea }\end{array}$ & $\begin{array}{l}\text { Mainly adipose tissue } \\
\text { Mostly fat with some } \\
\text { mucous glands }\end{array}$ \\
\hline
\end{tabular}

Constitutional symptoms, such as loss of weight, fatigue, night sweats, and fever, were of sufficient degree to suggest tuberculosis in two cases. One of these was treated in a sanatorium with phrenic crush and artificial pneumothorax (Watts, Claggett, and McDonald, 1946).

Characteristically, the tumour was mobile, and, when viewed through the bronchoscope, movement synchronous with respiration could be seen, as was noted by Brewin (1952), Kernan (1927), and also in the present case.

DURATION OF SYMPTOMS Symptoms had been present for from six weeks to 12 years. It is possible that in cases with a long history symptoms may have been due to co-existent chronic bronchitis or bronchiectasis. It is impossible to say which of the lesions pre-existed.

\section{SUMMARY}

A case of fatty tumour of the bronchus is described, presenting with respiratory symptoms and radiological changes suggestive of either tuberculosis or bronchial carcinoma.

Bronchoscopy revealed a mobile, pinkish tumour protruding from the orifice of the right upper lobe bronchus, resembling an adenoma.

Microscopically this was a mixed tumour composed of tissues occurring normally in the bronchus, with fat predominating.

The effect of this tumour was to produce collapse, infection, fibrosis, and emphysema in the right upper lobe.
Treatment was by excision of the right upper lobe with sleeve resection of the adjacent portion of the right main bronchus.

Published reports of cases of fatty tumour of the bronchus are reviewed.

It is concluded that fatty tumours of the bronchus usually present in middle age, with a male predominance. A history of respiratory symptoms for six months to 12 years is given, and the tumours involve the major bronchi.

We wish to thank Professor J. Gough and $\mathrm{Mr}$. T. H. L. Rosser for their advice and encouragement, and Mr. G. Haddock for his assistance with the photography.

\section{REFERENCES}

Alstead, S. (1932). A simple bronchial neoplasm. Lancet, 2, 339. Brewin, E. G. (1952). A case of lipoma of the bronchus treated by transpleural bronchotomy. Brit. J. Surg., 40, 282.

Carlisle, J. C., Leary, W. V., McDonald, J. R. (1951). Endobronchial lipoma, report of case. Proc. Mayo Clin., 26, 103.

Feller, A. (1922). l'ber ein lipomähnliches Hamar:om der Lunge. Virchows Arch. path. Anat., 236, 470.

Jackson, C. and Jackson, C. L. (1932). Benign tumours of the trachea and bronchi ; with especial reference to tumour-like formations of inflammatory origin. $J$. Amer. med. Ass.99, 1747.

Kernan, J. D (1927). Three unusual endoscopic cases. Laryngoscope (St. Louis), 37, 62.

Liebow, A. A., (1952). Tumors of the lower respiratory tract, Atlas of Tumor Pathology Section 5. Fascicle 17: p. 128. Armed Forces Institute of Pathology, Washington.

McGlade, T. H. (1939). Fibro-lipoma of the bronchus : report of a case. Ann. Otol. (St. Louis), 48, 240.

Myerson, M. C. (1928). Benign neoplasms of the bronchus. Report of a case of fibrolipoma of the left main bronchus removed through the bronchoscope. Amer. J. med. Sci., 176, 720.

Vinson, P. P., and Pembleton, W. E. (1942). Lipoma of left main bronchus: report of a case and review of literature. Arch. Otolaryng., 35, 868.

Watts, C. F., Clagett, O. T., and McDonald, J. R. (1946). Lipoma of the bronchus discussion of benign neoplasms and report of a case of endobronchial lipoma. J. thorac. Surg., 15, 132.

Wessler, H., and Rabin, C. B. (1932). Benign tumors of the bronchus. Amer. J. Sci., 183, 164.

Willis, R. A. (1960). Pathology of Tumours, p. 384. Butterworths, London. 